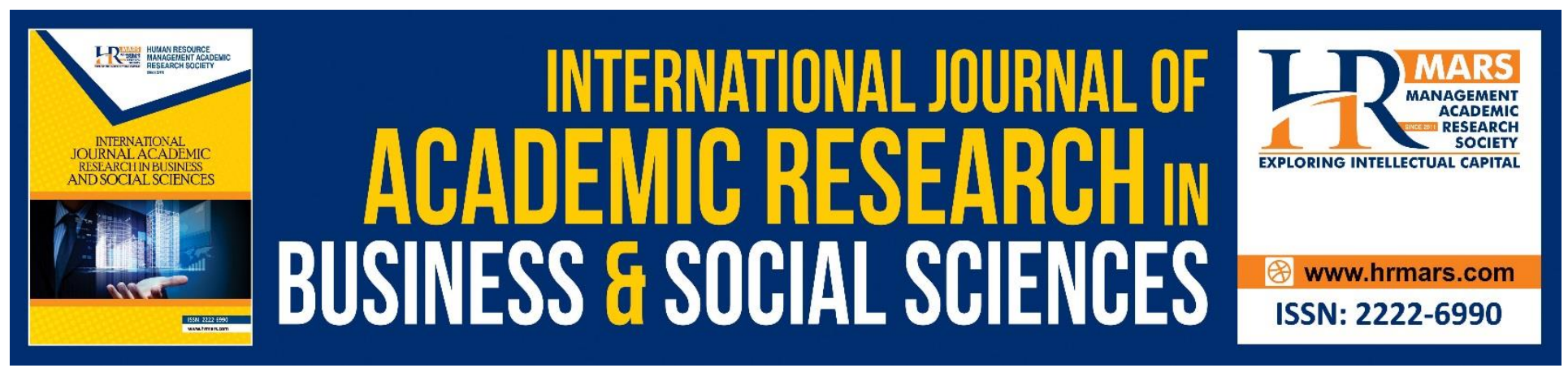

\title{
Drivers Influencing Financial Behavior among Management Students in Narowal
}

Awais Ahmad, Bushra Sohail Butt, Moazzam, Samia Iram

To Link this Article: http://dx.doi.org/10.6007/IJARBSS/v9-i2/5602 DOI: $10.6007 /$ IJARBSS/v9-i2/5602

Received: 17 Jan 2019, Revised: 26 Feb 2019, Accepted: 28 Feb 2019

Published Online: 03 March 2019

In-Text Citation: (Ahmad, Butt, Moazzam, \& Iram, 2019)

To Cite this Article: Ahmad, A., Butt, B. S., Moazzam, \& Iram, S. (2019). Drivers Influencing Financial Behavior among Management Students in Narowal. International Journal of Academic Research in Business and Social Sciences, 9(2), 656-666.

Copyright: (C) 2019 The Author(s)

Published by Human Resource Management Academic Research Society (www.hrmars.com)

This article is published under the Creative Commons Attribution (CC BY 4.0) license. Anyone may reproduce, distribute, translate and create derivative works of this article (for both commercial and non-commercial purposes), subject to full attribution to the original publication and authors. The full terms of this license may be seen at: http://creativecommons.org/licences/by/4.0/legalcode

Vol. 9, No. 2, 2019, Pg. 656 - 666

http://hrmars.com/index.php/pages/detail/IJARBSS

JOURNAL HOMEPAGE

Full Terms \& Conditions of access and use can be found at http://hrmars.com/index.php/pages/detail/publication-ethics 


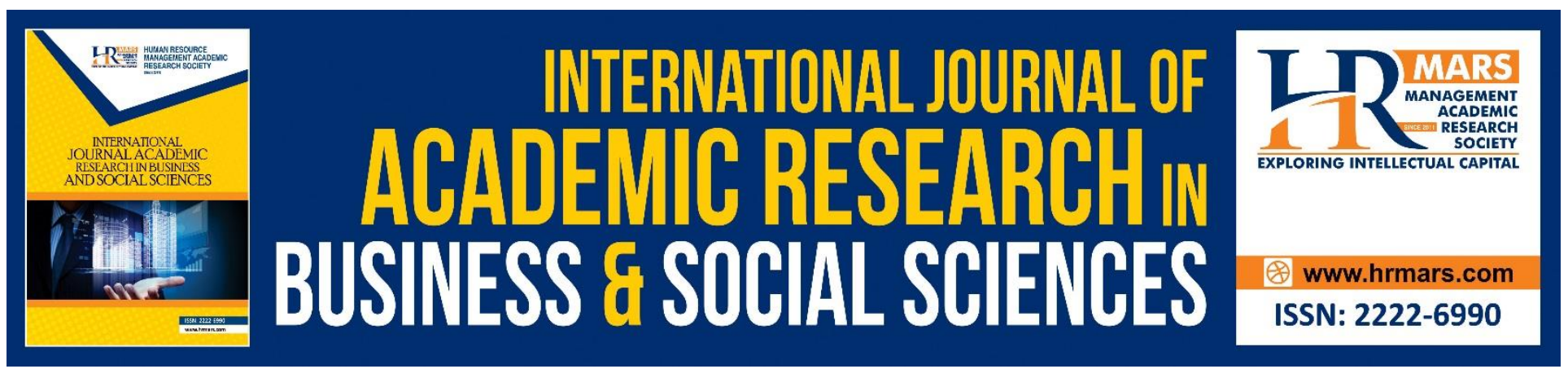

\title{
Drivers Influencing Financial Behavior among Management Students in Narowal
}

\author{
Awais Ahmad \\ Faculty of Management and Administration Sciences, University of Narowal, Punjab, Pakistan \\ Bushra Sohail Butt, Moazzam, Samia Iram \\ BBA Program, University of Narowal, Punjab Pakistan \\ Email: moazzamnwl@gmail.com
}

\begin{abstract}
The purpose of this study is to analyze the factors that influencing the financial behavior among universities and post graduate colleges student's in Narowal. The quantitative approach was used in this study by distributing questionnaires. A sum of total 237accurate and useable questionnaires have been received. Pearson correlation and multiple regression analysis were used for analyzing data. The empirical findings show that there is a direct positive and significant effect of financial attitude, financial knowledge, and financial self-efficacy on financial behavior. The financial self-efficacy has the highest contribution. This study also provides an opportunity for further researchers to use the financial satisfaction as a mediator.
\end{abstract}

Keywords: Financial Behavior, Financial Knowledge, Financial Self-Efficacy, Financial Attitude.

\section{Introduction}

Behavioral finance is comparatively newborn and advance field of study that spread behavioral psychology to economic decisions to guide and to understand why impartial people can usually make unsound decisions when they have money and want to invest. Behavioral finance is a framework that additive some part of standard finance and changes other parts.

Financial behavior is the credential to captive all the decision making of an individual, family, society or a state by understanding the impact of these decisions on a specific situation for right decisions related to their money management and also give them a chance for planning their expenses or savings.

In this study researcher mainly wanted to know which factors influences of financial behavior of a person? Financial knowledge is very important element through which financial behavior can be identified. Financial self-efficacy is another important element through that financial behavior 
influenced. When researchers examined the study then founded that financial attitude also has a great impact on financial behavior. Financial attitude play an effective role in demonstrating the accomplishment or disappointment of a person's financial behavior (Susan, 2018). Financial attitude by Eagly and chaiken (1993) explain the psychological inclination, the easiest way to understand liked or disliked attitude. Financial attitude demonstrate the smartness of an individual to select or reject an option of investment while making financial decisions. The greater the investors financial attitude, the greater the observance to invest its finances, so financial attitude have a great impact on financial behavior (Eagly, 1993).

Individuals must have knowledge to make planning or take decisions about their finance (Ibrahim, 2013). The mainly focus of this study are university students who have knowledge about financial management, because through learning financial management students get more financial information which is enough to enhance their financial knowledge and financial attitude. This research sample's knowledge related to finance is relatively high because the students which select as a sample are the universities student's and post graduate college's students in Narowal, so they have great information and knowledge regarding finance due to study the course of financial management.

The more knowledge an individual have about finance the more better the financial behavior of him. This type of behavior demonstrate that a person who have financial knowledge he/she must have more credentials to manage their financial affairs such as regulate their family needs, with sequent paying their bills, define saving patterns and for the future perspective better planning to manage their finance (Ida, 2010).

Financial self efficacy is a way in which an individual or a group of people realized that they are much efficient to handle or cope with a situation. Knowledge and self efficacy are the basis for behavioral changing to take place but both have a minor difference in the sense of efficacy; because self efficient people feel that they are capable to take efficient decisions about their financial affairs (Bandura, 1977). In the condition of either financial knowledge or either financial self-efficacy or may be both students have to be motivated to take decisions for improving their financial behavior (Sharon, 2017). This study inquires the behavior of the students of the universities and post graduate colleges about their financial affairs those who were incline by the variable of financial attitude, financial knowledge, and financial self-efficacy.

\section{Objectives}

1- To examine the relationship between financial knowledge and financial behavior.

2- To determine the impact of financial self-efficacy on financial behavior.

3- To access the effect of financial attitude on financial behavior.

\section{Literature Review}

Effect of Financial knowledge on financial behavior

Education can improve the financial knowledge of an individual. If more individuals get education then obviously their financial knowledge will be enhance due to the reason of their ability of choosing different tools of better financial investments. A person who has financial knowledge he will have been extra aware towards their future. So that, those persons are always strain to explore the 
INTERNATIONAL JOURNAL OF ACADEMIC RESEARCH IN BUSINESS AND SOCIAL SCIENCES

Vol. 9, No. 2, Feb, 2019, E-ISSN: 2222-6990 C 2019 HRMARS

different methods to secure their savings (Arifin, 2018). If a person has less financial knowledge than he may face different problems to managed their finance (Hilgert, 2003).

Many studies results shows that financial knowledge has direct positive and significant impact on financial behavior, which describe that the more financial knowledge a person has then it enhance the financial behavior (Hilgert, 2003, \& Herawati, 2018). The behavior which students learnt during their study is due to their financial literacy which impact on their future decision making. Another study shown that positive behavior due to financial knowledge related to managing finance enhance financial safety, decrease financial pressure and enhance person's self esteem (Kumar, 2017).

\section{Effect of financial self-efficacy on financial behavior}

Self efficacy is basically an individual's believe on himself that he or she has enough capabilities to manage their financial decisions and can take efficient decisions. In this research this variable is related to student's confidence in their personal capacity to transform financial conduct to a superior way. Nowadays financial instruction isn't the main component that can change individual budgetary conduct toward a superior way. "A central point affecting customer conduct is simply the inclination adequacy which is having the trust in one's capacity to manage a circumstance without being overpowered (Lown, 2011). So that, it shows that financial self-efficacy build a narrative in an individual's mind that about well managing their finance which impact on his behavior. Other study findings indicated that financial self-efficacy negatively effect on the students financial behavior regarding credit instruments utilization. This demonstrates that those students who consider themselves efficient in managing finance will decrease silly conducts. Accordingly to this situation, it may be inferred that financial self viability affects financial behavior. The higher an individual's financial self-efficacy the better their budgetary conduct (Kennedy, 2013).

\section{Effect of financial attitude on financial behavior}

For financial progress and failure financial attitude is playing an essential role. A Positive attitude will affect positive behavior. If an individual's financial attitude is good and appropriate then it must effect on financial behavior. Without the utilization of an appropriate attitude in financial behavior it is critical for students to save their investment in future (Ameliawat, 2018).

Financial attitude can be determine as mental tendency that expressed while assessing money management or taking financial decisions related to financial behavior (Parrotta, 1998). Many researches result support that financial attitude play a vital impact in demonstrating the financial behavior of an individual (Davis and Schumm, 1987, \& Shih, 2014). Financial attitude also define and develop the patterns of spending, savings, and idle money (Furnham, 1984).

\section{Hypotheses}

H1: Financial knowledge has a direct positive impact on financial behavior.

$\mathrm{H}$ 2: Financial self efficacy has a direct positive impact on financial behavior.

H3: Financial attitude has a direct positive impact on financial behavior.

\section{Methodology}


INTERNATIONAL JOURNAL OF ACADEMIC RESEARCH IN BUSINESS AND SOCIAL SCIENCES

Vol. 9, No. 2, Feb, 2019, E-ISSN: 2222-6990 C 2019 HRMARS

This study based upon the quantitative technique to analyze theories and variables with the help of following theoretical model. This model demonstrates that how financial knowledge, financial selfefficacy and financial attitude impact on the financial behavior of students.

Figure 1. Theoretical Model

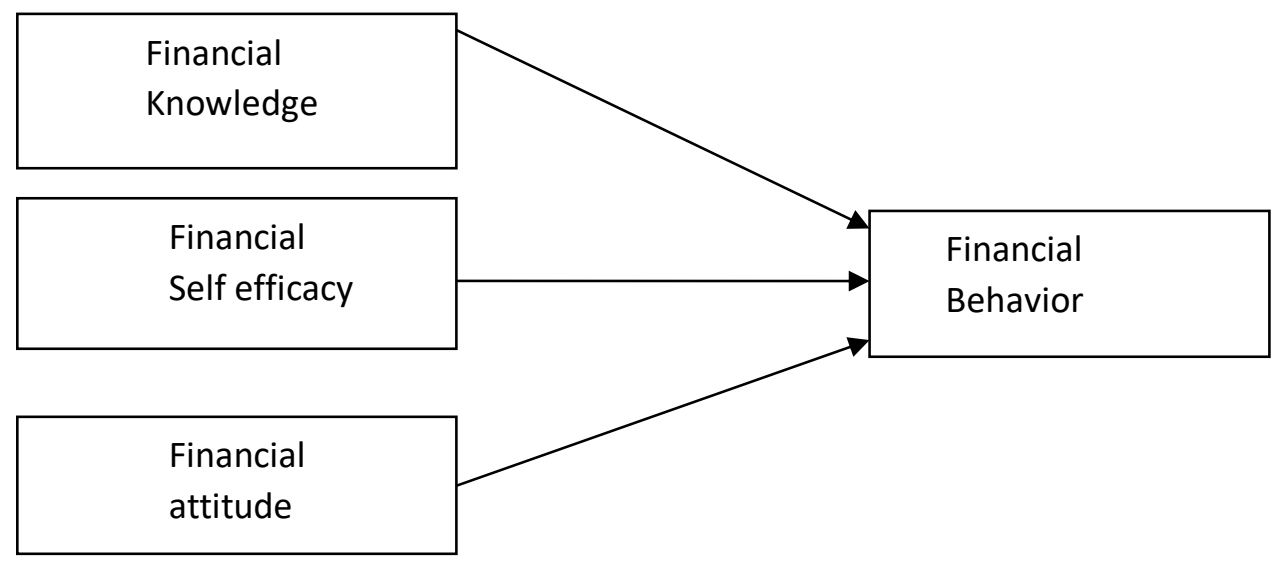

\section{Population and sample}

The target sector in this research was universities and Post graduate colleges in Narowal. The target population is the students of BBA, MBA and M.com who study the subject of financial management. Population was selected on the basis that the students who were studied financial management are able to response well about the drivers which impact on financial behavior. The sampling technique of this research was random sampling. This study's sample size was 280 students.

\section{Technique of Data Collection}

In this study the method of data collection was questionnaire. Questionnaire was anticipated to collect data about the financial behavior, financial attitude, financial self-efficacy and financial knowledge. A questionnaire of financial knowledge and financial attitude adopted the previous study of Setyawati, I. and suroso, S. (2016) item from 15 - 23. A questionnaire of financial self-efficacy adopt the previous study of Lown, J.M (2016) item from 1 to 5, the number 6 question was not considered because this question is related to job holder persons and in this research the respondent are students. A questionnaire of financial knowledge adopted previous study of RAJNA A/P R.ANTHONY (2011). Questionnaires were distributed to 280 students but 249 responses were collected in which 12 questionnaires were not completely filled so we get 237 exact filled questionnaires.

\section{Technique of Analyzing Data}

The total number of 237 respondents detail data entered into SPSS, and then the individual data analyzed in group basis. Descriptive statistics tells regarding the intensity of financial behavior, financial attitude, financial self-efficacy and financial knowledge which can be seen in the terms of 
INTERNATIONAL JOURNAL OF ACADEMIC RESEARCH IN BUSINESS AND SOCIAL SCIENCES

Vol. 9, No. 2, Feb, 2019, E-ISSN: 2222-6990 C 2019 HRMARS

mean, Skewness, Kurtosis, maximum and minimum. This study used the analysis of Cronbach's Alpha, the Pearson correlation and regression test to examine the relationship between variables.

\section{Results and Discussion}

\section{Normality Test}

Table 1 Descriptive analysis

\section{Statistics}

\begin{tabular}{|l|r|r|r|r|}
\hline & \multicolumn{1}{|c|}{ FB } & FA & FS & \multicolumn{1}{c|}{ FK } \\
\hline N Valid & 237 & 237 & 237 & 237 \\
Mean Missing & 0 & 0 & 0 & 0 \\
Skewness & 3.2764 & 3.3896 & 3.2027 & 3.3716 \\
Std. Error of & -.498 & -.597 & -.455 & -.714 \\
Skewness & .158 & .158 & .158 & .158 \\
Kurtosis & -1.313 & -1.061 & -.831 & -.666 \\
Std. Error of Kurtosis & .315 & .315 & .315 & .315 \\
Minimum & 1.33 & 1.00 & 1.00 & 1.57 \\
Maximum & 5.00 & 5.00 & 4.80 & 4.86 \\
\hline
\end{tabular}

Normality test is the test in which researcher were check the all data are normally distributed or not. This study results show that the value of skewness of all variables within the range of \pm 1 . The result of kurtosis show that the all variables value is with the range of \pm 3 . Thus the results show that data are normally distributed.

\section{Reliability Test}

The reliability test is a steady tool through which researcher easily check the reliability of data. In "SPSS" cronbach's Alpha test was used and the relative standard for this test is 0.70; it shows if the Cronbach's Alpha is 0.70 than it reliable.

\section{Reliability Statistics}

\begin{tabular}{|r|r|}
\hline $\begin{array}{c}\text { Cronbach's } \\
\text { Alpha }\end{array}$ & N of Items \\
\hline .849 & 4 \\
\hline
\end{tabular}

Table 2. Cornbach alpha test

According to the Table 2, which show that the "Cronbach's Alpha" value is .849. The Cronbach's Alpha value is more than 0.70 . So, that results of all variable and data are reliable.

\subsection{Pearson Correlation Analysis}

Correlation is the way of assessing or evaluating the relationship between variables. The Pearson correlation will indicate the strength and significance relationship between two variables.

Table 3 Pearson Correlation Results 
INTERNATIONAL JOURNAL OF ACADEMIC RESEARCH IN BUSINESS AND SOCIAL SCIENCES Vol. 9, No. 2, Feb, 2019, E-ISSN: 222 2-6990 (C) 2019 HRMARS

\begin{tabular}{|l|r|r|r|}
\hline & \multicolumn{1}{|l|}{$\begin{array}{l}\text { Financial } \\
\text { Attitude }\end{array}$} & \multicolumn{1}{|c|}{$\begin{array}{c}\text { Financial self- } \\
\text { efficacy }\end{array}$} & $\begin{array}{c}\text { Financial } \\
\text { knowledge }\end{array}$ \\
\hline Pearson Correlation & $.518^{* *}$ & $.579^{* *}$ & $.572^{* *}$ \\
Sig. (2-tailed) & .000 & .000 & .000 \\
N & 237 & 237 & 237 \\
\hline
\end{tabular}

${ }^{* *}$ Correlation is significant at the 0.01 level (2-tailed).

Relationship between financial attitude and financial behavior

Analysis in the above table 3, described that Pearson correlation between financial attitude and financial behavior results were positive. The value of Pearson correlation was .518 and the significance of the variable was 0.000 so that the significance was less than 0.05 . The results show that there is a moderate relationship between financial attitude and financial behavior.

Relationship between financial self-efficacy and financial behavior

Based on the above table 3, show that's the Pearson correlation results between financial selfefficacy and financial behavior value has significantly positive. The value of Pearson correlation is .579 and the significance value is .000 where the value of significance is less than 0.05 . The results show that there is fair positive and significance relationship between financial self-efficacy and financial behavior.

\section{Relationship between financial knowledge and financial behavior}

According to the results in the table 3 shows that the Pearson correlation between financial knowledge and financial behavior is positive. The Pearson correlation value which is .572 and the significance value is .000 , where the value of significance is less than the .05 . The result shows that there is moderate positive and significance relationship between financial knowledge and financial behavior.

\section{Regression Analysis}

Table 4 Model Summary

\begin{tabular}{|c|c|c|c|c|}
\hline Model & $\mathrm{R}$ & R Square & Adjusted R Square & $\begin{array}{l}\text { Std. Error of the } \\
\text { Estimate }\end{array}$ \\
\hline 1 & $.644^{\mathrm{a}}$ & .414 & .407 & .85665 \\
\hline
\end{tabular}

According to the above table 4 , it demonstrates that $R$ square is .414, which indicates that financial attitude, financial self-efficacy and financial behavior have impact up to $41.4 \%$ toward financial behavior among the management students in Narowal. On the other hand the multitude of the residue coefficient $(100-41.5)=58.5$ was clarified by alternate factors outside the model . 
INTERNATIONAL JOURNAL OF ACADEMIC RESEARCH IN BUSINESS AND SOCIAL SCIENCES

Vol. 9, No. 2, Feb, 2019, E-ISSN: 2222-6990 C 2019 HRMARS

\section{ANOVA Analysis}

Table 5 ANOVA $^{a}$

\begin{tabular}{|rl|r|r|r|r|r|}
\hline \multicolumn{1}{|l|}{ Model } & \multicolumn{1}{c|}{$\begin{array}{c}\text { Sum of } \\
\text { Squares }\end{array}$} & Df & Mean Square & F & Sig. \\
\hline \multirow{2}{*}{1} & Regression & 120.881 & 3 & 40.294 & 54.907 & $.000^{\mathrm{b}}$ \\
& Residual & 170.988 & 233 & .734 & & \\
& Total & 291.870 & 236 & & & \\
\hline
\end{tabular}

a. Dependent Variable: FB

b. Predictors: (Constant), FA, FS, FK

The F-test part in ANOVA analysis according to above table 5 the value of $F$ is 54.907 that is significant at level 0.000 . Hence, the overall regression model for financial attitude, financial self-efficacy and financial knowledge is appropriately describing the difference in financial behavior among management students in Narowal.

\subsection{Regression Coefficient}

Table 6

\section{Coefficient $^{\mathrm{a}}$}

\begin{tabular}{|rr|r|r|r|r|r|}
\hline \multicolumn{2}{|l|}{ Model } & \multicolumn{2}{|l|}{ Unstandardized Coefficients } & \multicolumn{1}{c|}{$\begin{array}{c}\text { Standardized } \\
\text { Coefficients }\end{array}$} & \multicolumn{1}{c|}{ Sig. } \\
\cline { 3 - 5 } & B & Std. Error & \multicolumn{1}{|c|}{ Beta } & & \\
\hline 1 & (Constant) & .490 & .237 & & 2.065 & .040 \\
& FA & .153 & .077 & .160 & 1.998 & .047 \\
& FS & .398 & .074 & .353 & 5.387 & .000 \\
& FK & .294 & .118 & .221 & 2.499 & .013 \\
\hline
\end{tabular}

a Dependent Variable: financial behavior

The analysis results in the table 6 describe, the equation of regression of the impact of financial attitude, financial self-efficacy and financial knowledge on financial behavior can be formulated as below:

Financial Behavior $(y)=0.160$ financial attitude +.353 finanical self-efficacy +.221 financial knowledge

From the table 6, financial attitude has significantly impact toward financial behavior the management students (sig. $=0.047, t=1.998, \beta=0.160$ ). The result indicates that if one unit increased in financial attitude, then it will lead to increase the financial attitude among management's students by 0.160 keep the all other variables constant. This research is also related to many other studies (Ameliawati, M. \& Setiyani, R. (2018); YAP, C, J, R., KOMALASARI, F. \& HADIANSAH, I. (2016)) who stated that financial attitude significantly effect on financial behavior.

From the coefficient table 6 , financial self-efficacy has significant positive influence toward financial behavior of management students (sig. $=0.00, t=5.387, \beta=.353$ ). The result indicates that if one unit increased in financial self-efficacy; it will direct to enhancing the financial self-efficacy among 
students by 0.353 keep the all other variables constant. This research is also related to other study (Herawati,T. N, Candiasa, M, Yadnyana, K \& Suharsono, N. (2018)).

From the coefficients table 6 , the financial knowledge has significant positive impact toward financial behavior among management students (sig. 0.013, $t=2.499, \beta=.221$ ). The result indicates the financial knowledge is increase by one unit; it will lead to increase the financial knowledge among management students by .221 keep all other variables constant. This research is also related to many other studies (YAP, C, J, R., KOMALASARI, F. \& HADIANSAH, I. (2016); Ida, and Dwinta. (2010)) who stated that financial knowledge significantly effect on financial behavior.

This research shows that all the independent variables (financial attitude, financial self-efficacy, and financial knowledge) have direct, significant and positive impact on the dependent variable (financial behavior). The result shows that financial knowledge, financial self-efficacy and financial attitude have positive value of beta but the financial self-efficacy has more impact or plays a vital role all than other independent variables in determining the financial behavior. This study's results also describe that variable's relations move to word positive way that means the greater the financial self-efficacy of the management students the more better their financial affairs. Financial self-efficacy determines that if the students have more self-efficacy then it will minimize their irrational credit seeking behavior (Kennedy \& Brian, 2013).

\section{Conclusion}

This study purpose was to exploring the impact of three financial behavior drivers (financial attitude, financial self-efficacy and financial knowledge) on financial behavior. Researchers wanted to know which factors influenced on financial behavior among management students in universities of Narowal who have studied financial management. The finding shows that all the variables are normally distributed and have a positive and significant impact on financial behavior. It is founded that financial attitude, financial self-efficacy and financial knowledge significantly demonstrate the financial behavior of an individual, group, or organization.

Our contribution in this study is firstly to add-up financial attitude as an independent variable and wanted to know its impact on financial behavior. Financial Attitude is an easiest way to explain a person's financial behavior through knowing the smartness of a person regarding their financial decisions. Another thing is that the researcher wanted to know the financial drivers (financial knowledge, financial self-efficacy, and financial attitude) impact of financial behavior among management students in the city Narowal.

\section{Limitations \& Future Research}

This study has certain limitations for example time, resources and small sample size used in this study for data collection. This study also provides an opportunity for further researchers to use the financial satisfaction as a mediator. Another limitation is to enlarge the sample size or to use the technique of multistage random sampling. 
INTERNATIONAL JOURNAL OF ACADEMIC RESEARCH IN BUSINESS AND SOCIAL SCIENCES

Vol. 9, No. 2, Feb, 2019, E-ISSN: 222 2-6990 (C) 2019 HRMARS

\section{References}

Arifin, Z.A. (2018) Influence factors towards satisfaction with financial behavior as intervening variable on Jakarta area workforce. Europeans Research Studies Journal, 21 (1), 90-103.

Ameliawati, M., \& Setiyani, R. (2018) The Influence of Financial Attitude, Financial Socialization, and Financial Experience to Financial Management Behavior with Financial Literacy as the Mediation Variable. International Conference on Economics, Business and Economic Education, 811-832.

Bandura, A. (1977). Self-efficacy: Toward a unifying theory of behavioral change. Psychological Review, 84(2), 191-215.

Eagly, A.H., and Chaiken, S. (1993) The Psychology of Attitudes. Harcourt Brace Jovanovich, Fort Worth, TX.

Furnham, A., 1984. Many sides of a coin: The psychology of money usage, Personality and Individual Differences, (5)5: 95-103.

Hilgert, A. M, Hogarth, M. J, and Beverly, G. S. (2003) Household financial management: The connection between knowledge and behavior. Federal Reserve Bulletin, 309-322.

Herawati,T. N, Candiasa, M, Yadnyana, K \& Suharsono, N. (2018) Factors That Influence Financial Behavior Among Accounting Students in Bali. International Journal of Business Administration, 9(3), 30-38.

Ibrahim, E.M, \& Alqaydi, R. F. (2013). Financial Literacy, Personal Financial Attitude, and Forms of Personal Debt among Residents of the UAE. International Journal of Economics and Finance, 5(7), 126-38.

Ida, and Dwinta. (2010). The influence of locus of control, financial knowledge and income to financial management behavior. Journal of Business and Accounting, 12(3), 131-144.

Kumar, S., Watung, C., Eunike, J., \& Liunata, L. (2017) The Influence of Financial Literacy Towards Financial Behavior and its Implication on Financial Decisions: A survey of President University Students in Cikarang - Bekasi. Firm journal of Management Studies. 2 (1), 169-179.

Kennedy P.B. (2013). The Theory of Planned Behavior and Financial Literacy: A Predictive Model For Credit Card Debt? Dissertations, 480. Retrieved 25 July 2016, https://mds.marshall.edu/cgi/viewcontent.cgi?referer=https://www.google.com/\&httpsre $\operatorname{dir}=1 \&$ article $=1480 \&$ context $=$ etd 
INTERNATIONAL JOURNAL OF ACADEMIC RESEARCH IN BUSINESS AND SOCIAL SCIENCES

Vol. 9, No. 2, Feb, 2019, E-ISSN: 2222-6990 C 2019 HRMARS

Lown, M. J. (2011). Outstanding AFCPE ${ }^{\circledR}$ Conference Paper: Development and Validation of a Financial Self-Efficacy Scale (8 February 2012). Journal of Financial Counseling and Planning, 22(2). https://www.afcpe.org/assets/pdf/vol_22_issue_2_lown.pdf

Parrotta, J.L., Johnson, P.J., 1998. The Impact of Financial Attitudes And Knowledge On Financial Management And Satisfaction Of Recently Married Individuals, Financial Counseling and Planning, 9(2), 59-75.

Anthony, A/p, R. (2011). Knowledge, attitude, practice and satisfaction on personal financial management among the medical practitioners in the public and private medical services in Malaysia.

Setyawati, I., Suroso, S. (2016). Sharia financial literacy and effect on social economic factors (Survey on lecturer in Indonesia). International journal of Scientific \& Technology Research, 5(2) 92102.

Susan, M. (2018). Financial behavior and problems among college student in Indonesia: the role of financial knowledge. International journal of engineering \& technology, 7 (3.25), 133-137.

Sharon, M. D, \& Heather R. H. (2007) Teen financial knowledge, self efficacy and behavior. Association of Financial Planning and Education, 18(2), 48-60.

Shih, T. Y., Ke, S. C., 2014. Determinates of financial behavior: insights into consumer money attitudes and financial literacy. Service Business, 8(2): 217-238.

Yap, C. J. R., Komalasari, F. \& Hadiansah, I. (2016). The Effect of Financial Literacy and Attitude on Financial Management Behavior and Satisfaction. International Journal of Administrative Science \& Organization, 23(3) 140-146. 